\title{
Knowledge marketing: M4I-mix model of evaluation
}

\author{
Nadiia Artyukhova ${ }^{1 *}$, Vita Hordiienko², Vira Motrechko ${ }^{3}$, and Serhii Kasian ${ }^{4}$ \\ ${ }^{1}$ Department of Marketing, Academic and Scientific Institute for Business, Economics and \\ Management, Sumy State University, Rimski-Korsakov St., 2, 40007, Sumy, Ukraine \\ ${ }^{2}$ Department of Management, Academic and Scientific Institute for Business, Economics and \\ Management, Sumy State University, Rimski-Korsakov St., 2, 40007, Sumy, Ukraine \\ ${ }^{3}$ Sumy city Council, Nezalezhnosti 2, Sumy, 40000, Ukraine \\ ${ }^{4}$ Department of Marketing, Faculty of Finances and Economics, Dnipro University of Technology, \\ Dmytra Yavornytskogo 19, 49005, Dnipro, Ukraine
}

\begin{abstract}
The article is devoted to studying knowledge marketing as a tool for promoting educational and scientific services from the developer (university) to the consumer (industry and business). The main stages of knowledge generation following the DIKW model and the procedure for their further implementation are shown. Based on the bibliometric analysis of keywords clusters and the most popular research topics in the field of "knowledge marketing", the relevance of implementing the chain "idea investigation - implementation - industry" was confirmed. The M4I-mix approach is proposed for detailing the main processes occurring at each stage of knowledge marketing and identifying significant indicators that should be influenced. Examples of using the M4I-mix approach to promote educational services and commercialize research results are given.
\end{abstract}

\section{Introduction}

Knowledge as an object of "selling" to a consumer is a specific product to which one should apply one's own promotion rules. The intangible nature of knowledge is transformed into material objects as a result of technical, organizational and other kinds of decisions.

At the stage of knowledge transformation, it is important to propose an algorithm for their successful promotion, substantiation of the practical significance and usefulness for consumers.

Knowledge marketing here plays an important role in the sequential process from knowledge generation (this stage can be described by the DIKW model [1]) to knowledge management (Fig. 1).

* Corresponding author: n.artyukhova@pohnp.sumdu.edu.ua 
The implementation of the knowledge marketing stage requires a clear understanding of the relationship between the product developer (knowledge generator, educational and scientific service provider) and the final product consumer. A product designer should not create a product "by itself" (which, in his opinion, will be in demand in the market), but a product in response to a consumer's request. At the same time, the developer and the consumer (if their actions are synchronized and subordinate to achieving one goal) simultaneously participate in the process of generating ideas (idea), checking its performance (investigation), bringing the idea to a practical solution (implementation) and setting the resulting solution into production (industry). In fact, after the final stage is completed, there is produced innovation - a product that is implemented and has a competitive advantage over analogues. In a pragmatic sense, innovation is not only a new idea but a practical case already implemented based on this idea, which has proved successful. This study is devoted to developing an algorithm for the successful implementation of the knowledge gained through the chain "idea - investigation - implementation - industry" to create innovation (marketing for innovation), which calls the proposed algorithm the M4I model.

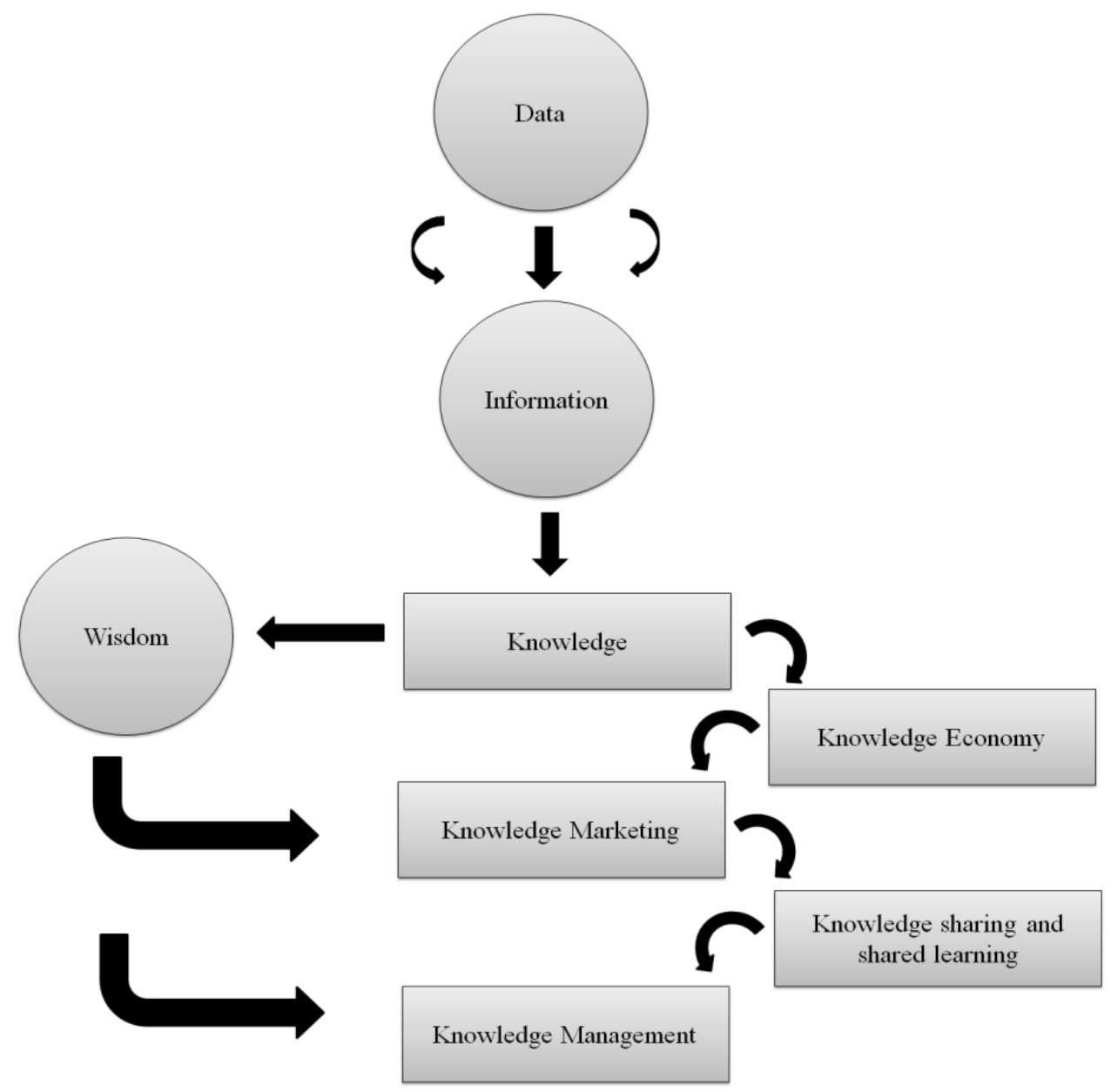

Fig. 1. From knowledge generation to knowledge management. 


\section{Literature Review}

Bibliometric analysis is known to be a useful tool for analysing the "knowledge marketing" scientific tenor. Based on the literary sources systematized by keywords, it is possible to obtain a picture of the relationship between different tenors, research clusters, the most promising topics for further study. Scopus scientometric database (https://www.scopus.com/) on publications and the software product VOSViewer were employed for the bibliometric analysis. The request was made using the keyword "knowledge marketing" with the selection of articles for the period 2000-2020 in the subject area "economics, econometrics and finance" (7347 articles). There were identified 15619 keywords which are reflected in the abstracts of scientific articles and are related to the indicated search query.

As a result of the selection by the indicator of the minimum number of references (the value 13 is taken), 396 keywords were obtained, which are summarized in the tree shown in Fig. 2.

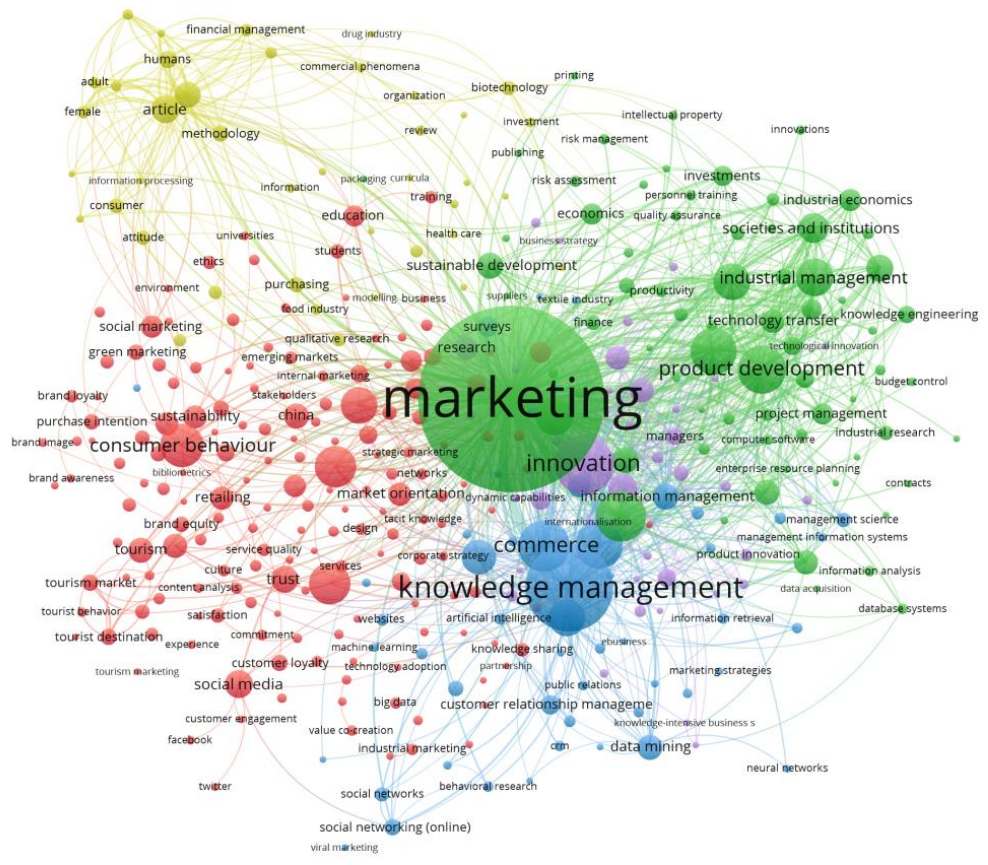

Fig. 2. Results of bibliometric analysis for the query "knowledge marketing".

Fig. 2 shows that researchers have established several clusters that consider various aspects of knowledge marketing regarding technology transfer, sustainable development, knowledge management, quality of education, etc. To check the correctness of choosing the M4I algorithm, a detailed analysis of the formed clusters was carried out. One cluster (Fig. 3) includes the study of the stages proposed in the M4I model confirming the relevance of research in this area.

In development, the SciVal tool performs a list of topics related to the tenor of "knowledge marketing" in the subject area of "economics, econometrics and finance" (20162020). Among the top $1 \%$ of topics by prominence, there are emphasised several practical topics that closely characterize the result of implementing the M4I model (Fig. 4).

In addition to bibliometric analysis, there were involved specific scientific works characterizing various aspects of the relationship among the stages of acquiring knowledge 
and its advancement. Analysis of the literature resources made it possible to generalize the following subjects of study:

- assessment of the innovation potential of the national economy [2-12];

- implementation of innovations into production and business [13-22];

- various aspects of the education quality impact on the educational services market [23-30];

- state regulation of the educational sector [31-36];

- building quality systems for education at universities [37];

- marketing and knowledge management regarding the goals of sustainable development [38-51];

- green marketing, green conscious and knowledge [52-54];

- development management [55-56].

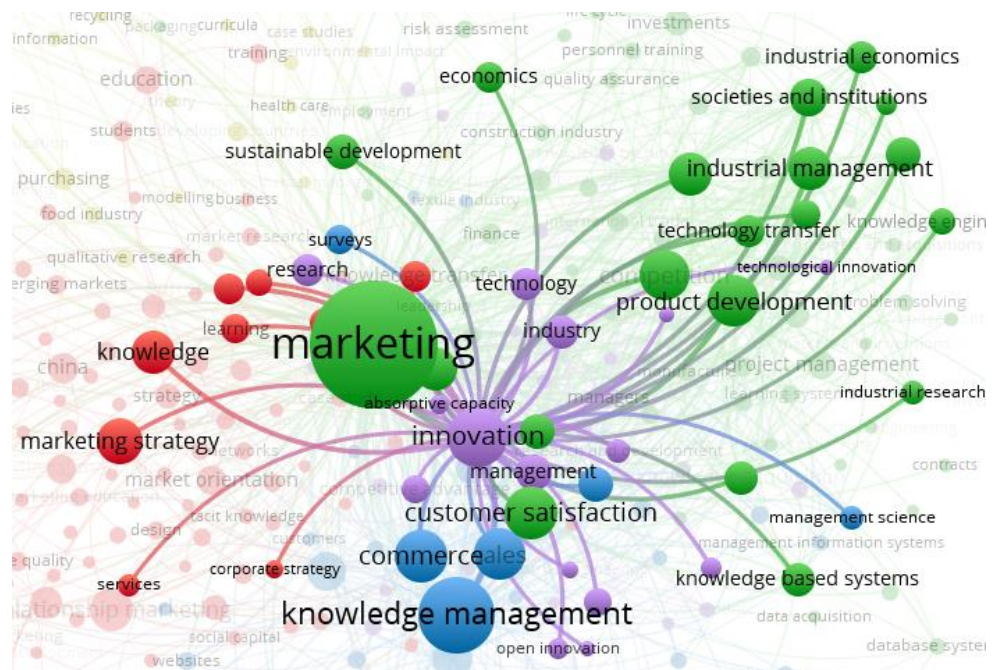

Fig. 3. M4I cluster. 


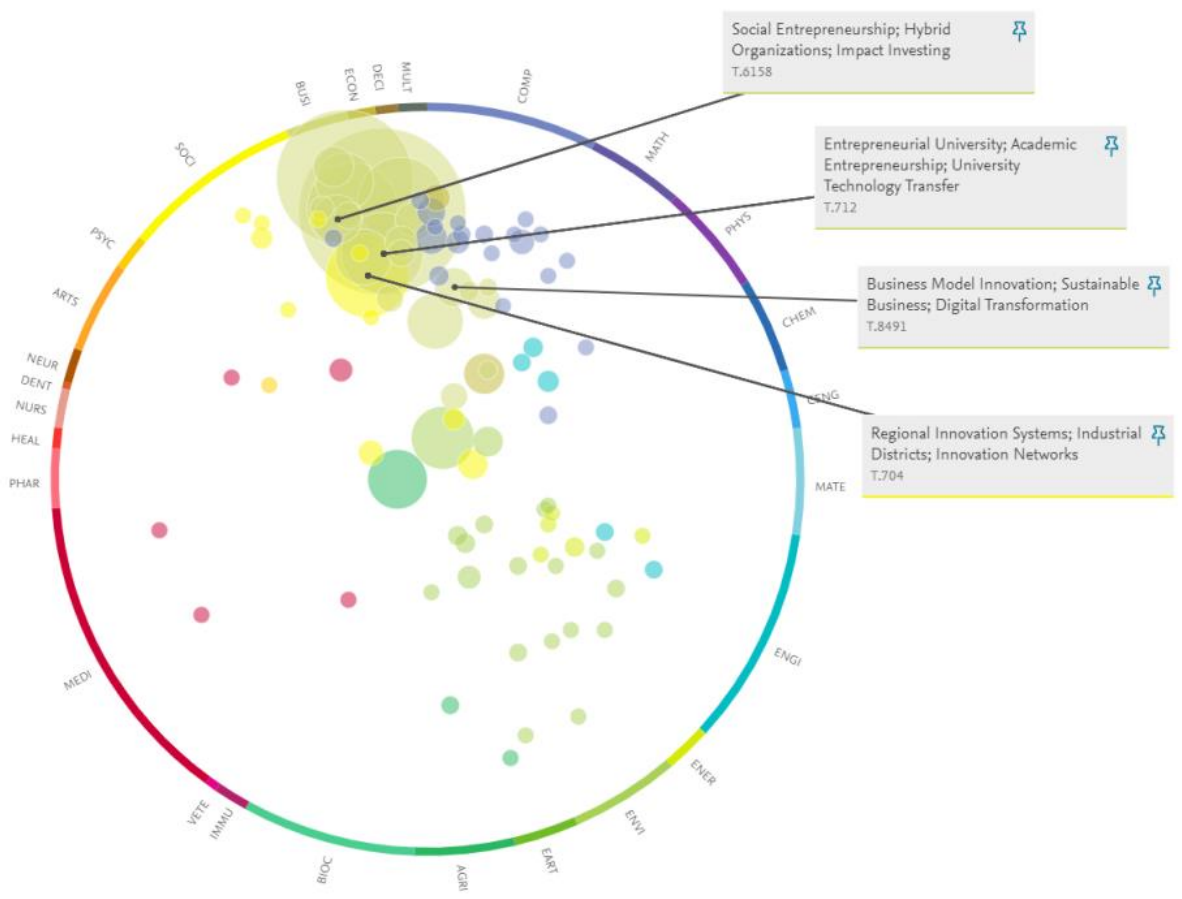

Fig. 4. Top $1 \%$ of topics by prominence for the query "knowledge marketing".

The indicated tenors are associated with various stages of implementing the M4I model and can be applied in particular cases on embedding knowledge into the real sector of the economy.

It should also be noted that an effective method in building the M4I model can be the use of the mix-marketing approach [157] at each stage of applying the main tasks for implementing knowledge. The combined M4I-mix model will be shown within the framework of this study, as well as examples of its use in promoting educational services and commercializing scientific research results.

\section{Results and Discussion}

The relationship among the main stages of the M4I model implementation and mix marketing can be represented as performed in Figure 5. The main idea of using mix-marketing in the proposed model is the detailing of the main processes occurring at each stage of knowledge marketing and the determination of significant indicators to be followed and influenced. 


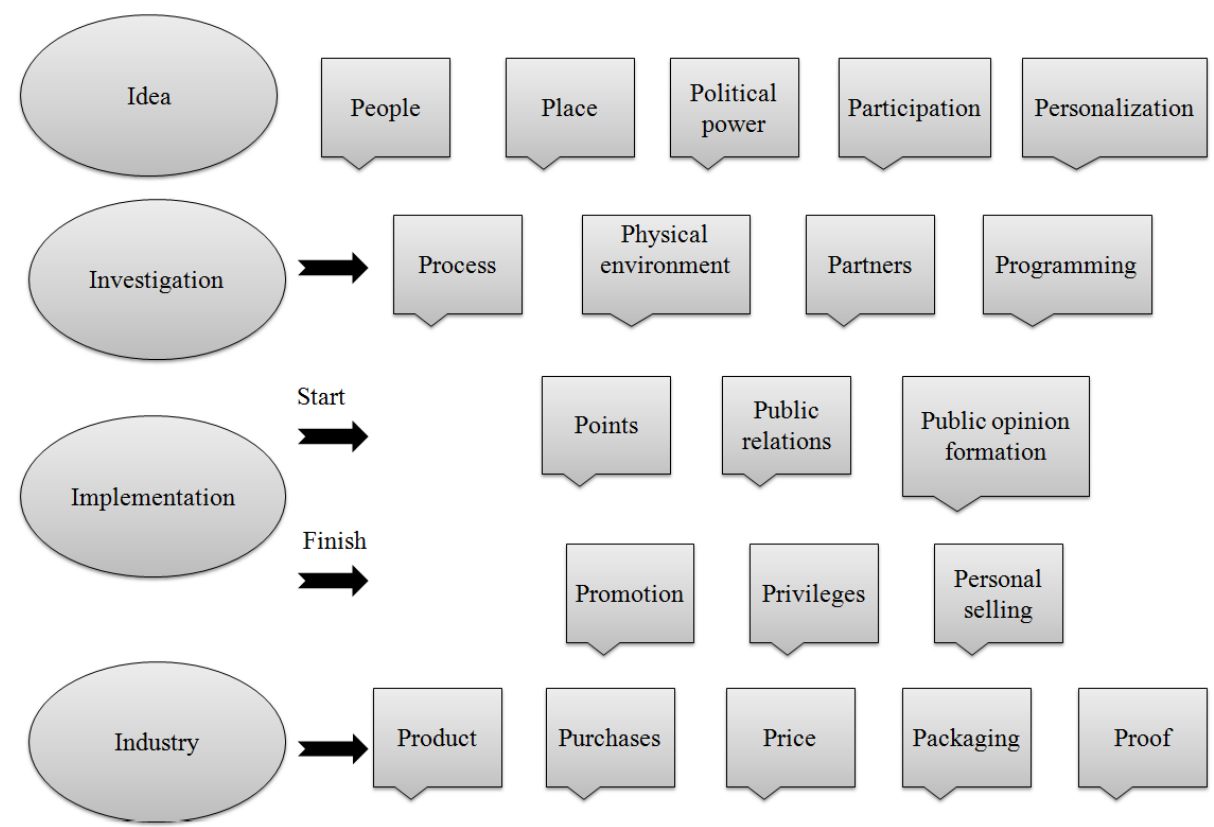

Fig. 5. M4I-mix model.

To demonstrate the essence of the M4I-mix model in the educational and scientific activities of the university, there will be given examples of choosing indicators according to the algorithm shown in Fig. 5. The role of university-wide services is not described within the frame presented below; attention is given to developers and consumers only. The proposed model allows the university's marketing service to see the process from the outside and use the necessary tools of influence in response to challenges at every stage.

Promotion of educational services.

Idea:

- people: teacher - student - employer;

- place: university;

- political power: state funding of students and training of personnel under contracts with industrial enterprises;

- participation: considering the stakeholders' opinion while designing educational programs;

- personalization: a graduate with a set of competencies and skills required by an employer.

Investigation:

- process: search for the optimal solution to implement the idea;

- physical environment: educational process;

- partners: stakeholders;

- programming: requirements for the quality of educational programs.

Implementation:

- points: competitive price and high quality;

- public relations: media space;

- public opinion shaping: the third mission of the university;

- promotion: a visiting card of an educational program;

- privileges: the right to choose an employer;

- personal selling: student contingent. 
Industry:

- product: educational program;

- purchases: educational infrastructure;

- price: the cost of training;

- packaging: educational unit (institute, faculty, department);

- proof: tuition fees.

Commercialization of scientific research results.

Idea:

- people: scientist - customer;

- place: university and its scientific infrastructure;

- political power: priority directions for developing science and technology;

- participation: considering the stakeholders' request while creating a scientific product;

- personalization: a scientific product ready for implementation.

Investigation:

- process: search for the optimal solution to implement the idea;

- physical environment: a research laboratory;

- partners: stakeholders;

- programming: product requirements.

Implementation:

- points: competitive price and high quality;

- public relations: media space;

- public opinion shaping: successful scientific and industrial projects.

- promotion: a technical and commercial offer;

- privileges: the right to choose the customer;

- personal selling: the number of customers;

Industry:

- product: scientific development;

- purchases: scientific infrastructure;

- price: the price of scientific development;

- packaging: technology transfer center;

- proof: payment for scientific development.

While comparing two options of the M4I-mix model implementation, the similar content of some stages can be seen. This is due to the development strategy implementation of the scientific, educational and industrial complex of the university. In this case, it is natural to single out individual indicators to which a similar approach is implemented, regardless of the promotion of educational or scientific products.

\section{Conclusions}

The M4I-mix model should become a useful tool for the effective promotion of knowledge to the market both in the form of educational services and in the form of scientific products. In all of the proposed options, each of the stages of the chain "idea - investigation implementation - industry" has clearly defined management indicators.

Considering that in the case of designing the ideal knowledge marketing mechanism, sooner or later, there will come a moment of dependence of services and developments sales on luck due to the paradox and the alignment of the general level of marketing strategies implementation.

However, under the real conditions of a university entering the market of educational and scientific services, the onset of the mastery paradox is a distant prospect. Therefore, at the 
present stage, under conditions of significant competition, the introduction of new approaches to the promotion of services will allow implementing the strategy of advanced development and obtaining the necessary competitive advantages for the development of its infrastructure.

Acknowledgments: This research was funded by the grant from the Ministry of Education and Science of Ukraine "Reforming the lifelong learning system in Ukraine for the prevention of the labor emigration: a coopetition model of institutional partnership" (reg. N. 0120U102001), "Convergence of economic and educational transformations in the digital society: modeling the impact on regional and national security "(reg. n. 0121U109553).

\section{References}

1. O. Dammann, Online journal of public health informatics, 10(3), e224 (2019)

2. T.A. Vasylieva, and V.O. Kasyanenko, Actual Problems of Economics, 144(6), 50 (2013)

3. Y. Kharazishvili, A. Kwilinski, O. Grishnova, H. Dzwigol, H. Sustainability, 12(21), 8953. (2020).

4. T. Vasilyeva, O. Kuzmenko, V. Bozhenko, and O. Kolotilina, CEUR Workshop Proceedings, 2422, 134 (2013)

5. H. Dzwigol, M. Dzwigol-Barosz, R. Miskiewicz, A. Kwilinski. Entrepreneurship and Sustainability Issues, 7(4), 2630-2644. (2020).

6. A. Sokolovska, T. Zatonatska, A. Stavytskyy, O. Lyulyov, V. Giedraitis. Research in World Economy, 11(4), 1-15. (2020).

7. O. Lyulyov, S. Lyeonov, I. Tiutiunyk, J. Podgórska. Journal of International Studies, 14(1), 139-152. (2021).

8. H. Dzwigol. Academy of Strategic Management Journal, 19(4), 1-8. (2020).

9. H. Dzwigol, M. Dźwigoł-Barosz, A. Kwilinski. Formation of Global Competitive Enterprise Environment Based on Industry 4.0 Concept. International Journal of Entrepreneurship, 24(1), 1-5. (2020).

10. H. Dzwigol. Meta-Analysis in Management and Quality Sciences. Marketing and Management of Innovation, 1, 324-335. (2021).

https://doi.org/10.21272/mmi.2021.1-25

11. L. Melnyk, L. Sineviciene, O. Lyulyov, T. Pimonenko, I. Dehtyarova. Problems and Perspectives in Management, 16(1), 105-114. (2018).

12. L. L. Hrytsenko, Actual Problems of Economics, 159(9), 84 (2014)

13. H. Dzwigol. Academy of Strategic Management Journal, 19(4), 1-8. (2020).

14. T. Vasilyeva, S. Bilan, K. Bagmet, and R. Seliga, Economics and Sociology, 13(1), 271 (2020)

15. R. Miskiewicz. Marketing and Management of Innovations, 3, 371-381. (2020) http://doi.org/10.21272/mmi.2020.3-27

16. N. Letunovska, L. Saher, T. Vasylieva, S. Lieonov. Paper presented at the E3S Web of Conferences, 250 (2021).

17. L. Saher, L. Syhyda, O. Korobets, T. Berezianko. Paper presented at the E3S Web of Conferences, , 234

18. Y. Bilan, T. Vasilyeva, O. Kryklii, and G. Shilimbetova, Creativity Studies, 12(1), 75 (2019)

19. A. Zakutniaia, and A. Hayriyan, Business Ethics and Leadership, 1(1), 46 (2017)

20. I. Kobushko, O. Jula, and M. Kolesnyk, SocioEconomic Challenges, 1(1), 60 (2017)

21. O.O. Zakharkin, I.V. Basantsov, I.O. Myroshnychenko, and V.O. Shcherbachenko, Espacios, 40(27) (2019) 
22. L. Sineviciene, O. Shkarupa, and L. Sysoyeva, SocioEconomic Challenges, 2(2), 81 (2018)

23. I.M. Boyarko, and Y.V. Samusevych, Actual Problems of Economics, 117(3), 86 (2011)

24. K. Onopriienko, V. Onopriienko, Y. Petrushenko, and I. Onopriienko, E3S Web Conf. 234, 00002 (2021)

25. P. Gallo, B. Mihalcova, O. Vegsoova, T. Dzurov-Vargova, N. Busova. Marketing and Management of Innovations, 2, 11-20. http://doi.org/10.21272/mmi.2019.2-01

26. S. Olena, and V. Tetyana, CEUR Workshop Proceedings, 2732, 1314 (2020)

27. O. Pavlenko, V. Martynets, O. Dreval, and D. Smolennikov, Quality - Access to Success, 21(176), 81 (2020)

28. H. Yarovenko, Y. Bilan, S. Lyeonov, and G. Mentel, Journal of Business Economics and Management, 22(2), 369 (2021)

29. S. Kvitka, G. Starushenko, V. Koval, H. Deforzh, and O. Prokopenko, Marketing and Management of Innovations, 3, 60 (2019)

30. S. Kolosok, V. Dementov, S. Korol, and O. Panchenko, Journal of Applied Economic Sciences, 13(8), 2375 (2018).

31. W. Sadiq, I. Abdullah, K. Aslam, S. Zulfiqar. Marketing and Management of Innovations, 1, 149-166. (2020).

32. S. Shkarlet, N. Kholiavko, M. Dubyna. Marketing and Management of Innovations, 3, 126-141. (2019).

33. Y. Petrushenko, N. Kostyuchenko, D. Smolennikov, and A. Vorontsova, Problems and Perspectives in Management, 15(3), 183 (2017)

34. C.G. Cosmulese, V. Grosu, E. Hlaciuc, A. Zhavoronok, Marketing and Management of Innovations, 3, 242 (2019)

35. V. Levchenko, A. Boyko, T. Savchenko, V. Bozhenko, Yu. Humenna, and R. Pilin, Marketing and Management of Innovations, 4, 364 (2019)

36. I. Skliar, Business Ethics and Leadership, 2(1), 96 (2018)

37. A. Teletov, S. Teletova, N. Letunovska. Periodicals of Engineering and Natural Sciences, 7(2), 458-465 (2019).

38. S. Olena, and V. Tetyana, CEUR Workshop Proceedings, 2732, 411 (2020)

39. A. Rosokhata, M. Minchenko, L. Khomenko, O. Chygryn. Paper presented at the E3S Web of Conferences, , 250 (2021)

40. I. Vakulenko, L. Saher, L. Syhyda, S. Kolosok, A. Yevdokymova. Paper presented at the E3S Web of Conferences, , 234

41. T. Pimonenko, O. Prokopenko, J. Dado. International Journal of Ecological Economics and Statistics, 38(4), 46-57. (2017).

42. A. Bondarenko, L. Zakharkina, L. Syhyda, L. Saher. International Journal of Sustainable Development and Planning, 15(4), 439-449 (2020).

43. A. Rosokhata, O. Rybina, A. Derykolenko, V. Makerska. Research in World Economy, 11 (4), 42-52 (2020).

44. O. Chygryn, A. Rosokhata, O. Rybina, N. \& Stoyanets. Paper presented at the E3S Web of Conferences, , 234 (2021).

45. B.A. Brimah, W.D. Olanipekun, A.G. Bamidele, and M. Ibrahim, Financial Markets, Institutions and Risks, 4(2), 34 (2020)

46. T. Vasylieva, O. Radchenko, and Y. Kryvych, Economic Annals-XXI, 7-8, 65 (2014)

47. F. Vidic, SocioEconomic Challenges, 3(2), 37 (2018)

48. A. Vorontsova, T. Vasylieva, Y. Bilan, G. Ostasz, and T. Mayboroda, Administratie Si Management Public, 2020(34), 6 (2020)

49. A. Karaoulanis, Business Ethics and Leadership, 2(2), 49 (2018)

50. A. Vorontsova, H. Shvindina, T. Mayboroda, H. Mishenina, and I. Heiets, Problems and Perspectives in Management, 18(4), 275 (2020) 
51. Yu. Prudnikov, and A. Nazarenko, Health Economics and Management Review, 2(1), $23(2021)$

52. O. Lyulyov, T. Pimonenko, A. Kwilinski, H. Dzwigol, M. Dzwigol-Barosz, V. Pavlyk, P. Barosz. Energies, 14(2). (2021).

53. N. Letunovska, O. Lyuolyov, T. Pimonenko, V. Aleksandrov. Paper presented at the E3S Web of Conferences, , 234

54. O. Prokopenko, J. Cebula, S. Chayen, T. Pimonenk. International Journal of Ecology and Development, 32(1), 98-107. (2017).

55. O. Lyulyov, Y. Chortok, T. Pimonenko, O. Borovik. International Journal of Ecology and Development, 30(3), 1-10. (2015).

56. B.R. Londhe, Procedia Economics and Finance, 11, 335 (2014) 